\title{
PENGEMBANGAN ALAT PERAGA FISIKA BERBASIS HOME MATERIAL MATERI SUHU DAN KALOR
}

\author{
Fitriah $^{1)}$, Linda Sekar Utami ${ }^{1}$, Johri Sabaryati ${ }^{1}$, M. Isnaini ${ }^{1)}$ \\ ${ }^{1)}$ Program Studi Pendidikan Fisika, FKIP, Universitas Muhammadiyah Mataram, NTB, Indonesia \\ Corresponding author : Linda Sekar Utami \\ E-mail : lindasekarutami@gmail.com
}

Diterima 25 April 2020, Direvisi 29 April 2020, Disetujui 5 Mei 2020

\begin{abstract}
ABSTRAK
Penelitian ini bertujuan mengembangkan alat peraga pembelajaran berbasis home materials pada materi suhu dan kalor untuk meningkatkan kreativitas belajar siswa kelas VII. Metode yang digunakan dalam penelitian ini adalah metode research and development yang dikembangkan Sugiyono dengan langkah-langkah : (1) Potensi dan Masalah, (2) Pengumpulan Data, (3) Desain Produk, (4) Validasi Desain, (5) Uji Coba Pemakaian, (6) Revisi Produk, (7) Uji Coba Produk, (8) Revisi Desain, (9) Revisi Produk, (10) Produksi massal. Alat peraga yang dikembangkan akan melalui tahap validasi yang dilakukan oleh ahli materi, ahli media, guru pengajar, dan siswa. Pengumpulan data dilakukan dengan teknik observasi, dokumentasi, angket dan tes uraian. Untuk mengetahui alat peraga dapat meningkatkan kreativitas belajar siswa kelas VII diuji keefektifannya menggunakan uji Gain Skor. Hasil penelitian menunjukkan bahwa alat peraga pembelajaran dapat meningkatkan kreativitas siswa hal ini ditunjukkan dengan nilai rata-rata siswa sebelum menggunakan alat peraga yaitu sebesar 46 dan setelah menggunakan alat peraga nilai rata-rata siswa menjadi 86 dan besar nilai n-gain diperoleh 0,74. Berdasarkan hasil penelitian ini dapat disimpulkan bahwa alat peraga pembelajaran dapat meningkatkan kreativitas belajar siswa kelas VII F SMPN 19 Mataram.
\end{abstract}

Kata kunci : pengembangan alat peraga fisika; materi suhu dan kalor.

\begin{abstract}
This study aims to develop teaching aids based on home materials on temperature and heat to improve the learning creativity of grade VII students. The method used in this research is the research and development method developed by Sugiyono with the following steps: (1) Potential and Problems, (2) Data Collection, (3) Product Design, (4) Design Validation, (5) Usage Trial , (6) Product Revision, (7) Product Trial, (8) Design Revision, (9) Product Revision, (10) Mass production. The teaching aids developed will go through a validation stage carried out by material experts, media experts, teaching teachers, and students. The data were collected by means of observation, documentation, questionnaires and test descriptions. To find out that the props can improve the learning creativity of class VII students, their effectiveness is tested using the Gain Score test. The results showed that learning aids could increase students 'creativity. This was indicated by the mean score of students before using props which was 46 and after using props the students' average score was 86 and the n-gain value was 0.74 . Based on the results of this study it can be concluded that the teaching aids can increase the learning creativity of class VII F students of SMPN 19 Mataram.
\end{abstract}

Keywords : physics teaching aids development; temperature and heat material.

\section{PENDAHULUAN}

IImu Pengetahuan Alam (IPA)

berkaitan dengan cara mencari tahu tentang alam secara sistematis, sehingga IPA tidak hanya berupa penguasaan kumpulan pengetahuan berupa fakta, konsep, atau prinsip saja, tetapi IPA juga merupakan suatu proses penemuan. Pendidikan IPA diharapkan dapat menjadi wahana bagi siswa untuk mempelajari diri sendiri dan alam sekitar, serta dapat menerapkannya dalam kehidupan sehari-hari.
Proses pembelajarannya diharapkan menekankan pada pembelajaran Saling temas (Sains, lingkungan, teknologi, dan masyarakat) secara terpadu yang diarahkan pada pemberian pengalaman secara langsung, sehingga siswa memperoleh pemahaman ilmiah yang lebih berkesan dan lebih mendalam. IPA adalah pelajaran yang penting karena ilmunya dapat diterapkan secara langsung dalam masyarakat. Beberapa alasan pentingnya mata pelajaran IPA yaitu, IPA 
berguna bagi kehidupan atau pekerjaan anak dikemudian hari, bagian kebudayaan bangsa, melatih anak berpikir kritis, dan mempunyai nilai-nilai pendidikan yaitu mempunyai potensi dapat membentuk pribadi anak secara keseluruhan oleh (Diatri : 2014: 9).

Salah satu hal penting yang mendukung pembelajaran IPA agar penyampaian konsep dapat lebih baik yaitu dengan menggunakan media pembelajaran, salah satunya berupa alat peraga.Alat peraga merupakan media pembelajaran yang efektif, menarik, dan efisien untuk membantu siswa dalam mencapai tujuan pembelajaran. Kegiatan percobaan dengan menggunakan alat peraga juga akan memudahkan siswa untuk memahami materi yang bersifat abstrak menjadi lebih konkrit oleh (Diatri : 2014: 12).

Berdasarkan hasil observasi di SMPN 19 Mataram, penggunaan alat peraga sebagai media pembelajaran masih sangat jarang dilakukan. Guru IPA biasanya hanya menggunakan media pembelajaran berupa buku dan papan tulis sedangkan percobaan hanya dilakukan pada materi tertentu dan hanya menggunakan metode demonstrasi. Hal ini dikarenakan belum tersedianya KIT praktikum di sekolah.Alat peraga IPA yang dimiliki hanya rangka dan torso, sedangkan alat peraga IPA untuk materi fisika masih belum tersedia.Minimnya fasilitas alat peraga ini menyebabkan kurangnya tingkat pemahaman siswa pada materi IPA yang bersifat abstrak, khususnya pada materi suhu dan kalor.

Pada pembelajaran IPA khususnya materi termometer, suhu dan kalor keterbatasan alat peraga ini dapat diatasi dengan mengembangkan alat peraga pembelajaran yang berbasis home materials. Home materials yang dimaksud di sini adalah penggunaan alat dan bahan yang sederhana, murah, dan mudah didapatkan dari lingkungan sekitar.

Alat peraga berbasis home materials merupakan alat yang dimodifikasi dari alat dan bahan yang sederhana, murah, dan mudah didapatkan di lingkungan sekitar yang dapat dijadikan peraga pembelajaran (Dewi, 2011: 7).

Kelebihan termometer sederhana ini adalah untuk mengukur suhu dimana suhu adalah besaran yang menyatakan derajat panas dingin suatu benda dan alat yang digunakan untuk mengukur suhu adalah termometer dalam kehidupan sehari-hari masyarakat untuk mengukur suhu cenderung menggunakan indera peraba.Tetapi dengan adanya perkembangan teknologi maka diciptakanlah termometer untuk mengukur suhu.

Penggunaan alat peraga perlu dilengkapi dengan Lembar Kerja Siswa (LKS) sebagai panduan untuk melakukan percobaan dan penuntun siswa untuk dapat menarik kesimpulan dari data hasil pengamatan menggunakan alat peraga tersebut.

Berdasarkan latar belakang masalah tersebut, maka penulis telah melakukan pengembangan alat peraga fisika materi suhu dan kalor berbasis home materials pada kelas VII SMP diharapkan dengan penggunaan alat peraga ini memberikan kemudahan serta inspirasi anak-anak untuk belajar.

Dengan pengembangan alat peraga termometer sederhana ini diharapkan para siswa lebih termotivasi untuk belajar físika, baik belajar terbimbing maupun belajar mandiri. Selain itu juga proses belajar mengajar seperti ini akan menjadikan kedudukan siswa dalam belajar tidak hanya sebagai obyek melainkan juga sebagai subyek belajar.

\section{METODE PENELITIAN Jenis Penelitian}

Jenis penelitian ini adalah penelitian pengembangan (Reseach \& Development). Reseach \& Development adalah metode penelitian yang digunakan untuk menghasilkan produk, Produk yang dihasilkan dalam penelitian pengembangan ini Pengembangan yang dilakukan adalah pembuatan media pembelajaran berupa alat peraga. Penelitian pengembangan merupakan kegiatan mengembangkan suatu produk baru atau menyempurnakan produk yang telah ada (Borg dan Gall, 1989:784).

Desain penelitian ini menggunakan satu kelas sampel sebagai kelas uji coba (One Group Pre- Test and Post-test Design).Teknik pengumpulan data pada penelitian ini adalah angket dan dokumentasi. Angket digunakan untuk mengumpulkan data tentang kelayakan media pembelajaran berupa alat peraga yang dibuat dan akan dijawab oleh responden yang terkait pembelajaran antara lain: ahi materi, ahli media, guru pengajar dan siswa sebagai pengguna media pembelajaran berupa alat peraga sederhana"Termometer".

Penelitian ini akan dilaksakan di

Sekolah Menengah Pertama (SMPN) 19 Mataram melibatkan siswa kelas VII.

\section{Prosedur Penelitian}

Langkah-langkah penelitian dan pengembangan alat peraga sederhana sebagai berikut: Sugiyono (2010 : 409). 


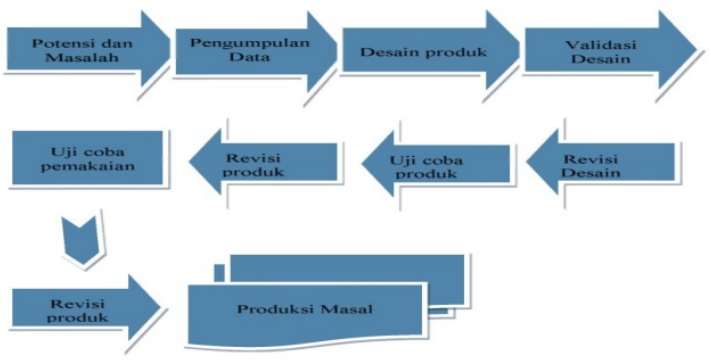

Gambar 1. Langkah-langkah penggunaan Metode research and development (R \& D)

Gambar 1 Langkah-langkah penggunaan Metode research and development (R \& D)

Penelitian ini dilakukan sampai pada tahap uji coba produk karena keterbatasan waktu dan dana. Media dikatakan valid apabila telah divalidasi oleh ahli dan diuji kefektifannya oleh peneliti dengan adanya peningkatan kreativitas belajar pada diri masing-masing siswa.

\section{Metode Penelitian Tahap I \\ Potensi dan Masalah}

Penelitian dapat berangkat dari potensi dan masalah yang ada. Potensi adalah segala sesuatu yang bila didayagunakan akan memiliki nilai tambah (Borg dan Gall, 1989:787). Potensi yang ditemukan dalam
penelitian ini adalah alat peraga "termometer" dalam kegiatan pembelajaran. Masalah dalam penelitian ini adalah kurangnya kreativitas belajar siswa kelas VII SMPN 19 Mataram terhadap mata pelajaran Fisika(Borg dan Gall, 1989:787).

\section{Mengumpulkan Data}

Penelitian $\begin{array}{r}\text { pengumpulan data } \\ \text { dilakukan untuk mengumpulkan informasi } \\ \text { sehingga }\end{array}$
masalah sehingga masalah dapat
teridentifikasi.Penelitian dan pengumpulan data ini menggunakan observasi sarana dan prasarana sekolah dan angket analisis kebutuhan.Observasi sarana dan prasarana meliputi ketersediaan fasilitas pendukung yang menunjangproses pembelajaran IPA dan sumber daya sekolah. Analisis kebutuhan dilakukan untuk mengumpulkan informasi tentang apa yang dibutuhkan siswa dan guru pada khususnya, dan sekolah pada umumnya, serta untuk mengetahui apakah guru dan siswa membutuhkan alat peraga pembelajaran dalam pembelajaran alat peraga materi suhu dan kalor. Hal inilah yang digunakan sebagai dasar dan latar belakang dalam pengembangan alat peraga yang dibuat.

\section{Desain Produk}

Pengembangan alat peraga yang dikembangkan yaitu membuat produk yang berupa alat peraga termometer sederhana.Produk yang dihasilkan dari penelitian pengembangan ini berupa alat peraga Termometer materi suhu dan kalor, untuk SMP yang disertai dengan LKS panduan praktikumnya. Kegiatan validasi isi ini akan dilakukan oleh ahli media pembelajaran dan bahan ajar fisika dengan cara mengisi instrument berupa angket dan memberi kritis atau saran terhadap produk pengembangan. Validasi isi dilakukan agar mengetahui kelayakan isi produk yang dikembangkan.

Validasi ahli pada pengembangan alat peraga Termometer merupakantiga orang dosen ahli media,ahli materi(konsep dan bahasa) dan satu orang guru SMPN 19 Mataram. Kriteria dosen diantaranya minimal menempuh pendidikan S2 dan guru di SMPN 19 Mataram minimal menempuh pendidikan S1 dan berpengalaman mengajar matari suhu dan kalor Ahli media yang telah menjadi validator produk pengembangan merupakan dosen yang memiliki menguasai bidang alat peraga pembelajaran yang telah berpengalaman dan telah menempuh pendidikan minimal S2 dan guru SMPN 19 Mataram minimal menempuh pendidikan S1.

\section{Validasi Produk}

Validasi produk dapat dilakukan dengan cara menghadirkan beberapa pakar tenaga ahli yang sudah berpengalaman untuk menilai produk baru yang dirancang tersebut Borg dan Gall, validasi isi dilakukan oleh para ahli bidang studi, ahli pengukuran, dan pakar yang memiliki keahlian yang relevan dengan bidang kajiannya (Borg dan Gall, 1989:789).

Kegiatan validasi isi ini akan dilakukan oleh ahli media pembelajaran dan ahli materi Fisika dengan cara mengisi instrumen berupa angket dan memberi kritik atau saran terhadap produk pengembangan. Validasi isi dilakukan agar mengetahui kelayakan isi produk yang dikembangkan. Validasi ahli pada pengembangan alat peraga termometer sederhana merupakan tiga orang dosen dan satu orang guru Fisika SMPN 19 Mataram. Kriteria dosen diantaranya minimal menempuh pendidikan S2 dan guru di SMPN 19 Mataram minimal menempuh pendidikan $\mathrm{S} 1$ dan berpengalaman mengajar materi termometer,suhu dan kalor.

\section{Instrumen Pengumpulan Data}

Data dalam penelitian pengembangan ini dikumpulkan menggunakan instrumen berupa lembar observasi dan angket. 
Observasi ialah pengamatan dan pencatatan yang sistematis tehadap gejala-gejala yang diteliti. Angket merupakan sejumlah pertanyaan tertulis yang digunakan untuk memperoleh informasi.Penulis lebih banyak menggunakan angket tertutup untuk memudahkan dalam menganalisis data daripada angket terbuka yang jawaban pertanyaannya dibebaskan kepada responden.Secara lengkap instrumen dapat dilihat pada lampiran.

Tabel 1. Kisi-Kisi Instrumen

\begin{tabular}{|c|c|c|}
\hline \multicolumn{2}{|r|}{ Tabel } & isi-Kisi Instrumen \\
\hline Jenis & Subjek & Kisi - kisi instrumen \\
\hline Penelitian & $\begin{array}{llr}\text { Guru } & \text { IPA } & \text { dan } \\
\text { siswa } & \text { SMPN } & 19 \\
\text { Mataram } & \\
\end{array}$ & $\begin{array}{l}\text { 1. Lembar observasi sarana dan prasarana } \\
\text { sekolah } \\
\text { 2. Angket analisis kebutuhan }\end{array}$ \\
\hline Uji ahli & $\begin{array}{l}\text { Pakar fisika dan } \\
\text { guru fisika } \\
\text { Guru fisika }\end{array}$ & $\begin{array}{l}\text { 1. Angket kesesuaian desain dengan } \\
\text { spesifikasi yang direncanakan } \\
\text { 2. Evaluasi dalam perencanaan } \\
\text { pembelajaran }\end{array}$ \\
\hline Uji LKS & $\begin{array}{l}\text { Pakar fisika dan } \\
\text { guru fisika } \\
\text { Guru fisika }\end{array}$ & $\begin{array}{l}\text { 1. Angket uji kelayakan isi } \\
\text { 2. Angket uji kesesuaian isi } \\
\text { 3. Angket uji kelayakan penyajian } \\
\text { 4. Angket uji kelayakan bahasa }\end{array}$ \\
\hline $\begin{array}{l}\text { Uji } \\
\text { lapangan }\end{array}$ & $\begin{array}{l}\text { Siswa SMPN } 19 \\
\text { Mataram } \\
\text { kelas VII }\end{array}$ & $\begin{array}{l}\text { 1. Angket kemenarikan, kemudahan, dan } \\
\text { kemanfaatan alat peraga } \\
\text { 2. Tes tertulis keefektifan alat peraga }\end{array}$ \\
\hline
\end{tabular}

(Diatri,2014)

Skala pengukuran yang digunakan dalam angket validasi produk adalah skala Likert adalah sebagai berikut:

1. Sangat Setuju (Sangat Positif) diberi skor 5

2. Setuju (Positif) diberi skor 4

3. Kurang Setuju (Negatif) diberi skor 3

4. Tidak Setuju (Sangat Negatif) diberiskor 2

5. Sangat Tidak Setuju (Sangat Negatif) diberi skor 1

\section{Teknik Analisis Data}

Data hasil analisis kebutuhan yang diperoleh dari guru dan siswa digunakan untuk menyusun latar belakang dan mengetahui tingkat keterbutuhan program pengembangan.Data hasil identifikasi kebutuhan ini dilengkapi dengan data hasil identifikasi sumber daya yang digunakan untuk menentukan spesifikasi produk yang dikembangkan.

Data kesesuaian desain dan materi pembelajaran pada produk diperoleh dari ahli materi, ahli desain atau praktisi melalui uji ahli atau validasi ahli produk. Data kesesuaian tersebut digunakan untuk mengetahui tingkat kelayakan produk yang dihasilkan untuk digunakan sebagai media pembelajaran.Data kemenarikan, kemudahan penggunaan, dan kemanfaatan produk diperoleh melalui uji lapangan kepada pengguna secara langung.Sedangkan data hasil belajar yang diperoleh melalui tes setelah penggunaan produk digunakan untuk menentukan tingkat efektivitas produk sebagai media pembelajaran. Analisis data berdasarkan instrumen uji ahli dan uji lapangan dilakukan untuk menilai sesuai atau tidaknya produk yang dihasilkan sebagai sumber belajar dan media pembelajaran.Instrumen penilaian ini memiliki empat pilihan jawaban sesuai konten pertanyaan yang masing-masing pilihan jawaban memiliki skor berbeda.

\section{Metode Penelitian Tahap II \\ Model Rancangan Eksperimen untuk Menguji}

Tujuan uji lapangan produk utama adalah untuk mengetahui apakah produk yang dikembangkan telah memenuhi tujuan.

\section{Subjek Uji Coba}

Adapun subjek uji coba yang akan diteliti pada penelitian ini adalah peserta didik kelas VII.

\section{Teknik Pengumpulan Data}

Teknik pengumpulan data kreativitas siswa adalah mengunakan angket kreativitas belajar yang diberikan sebelum menggunakan alat peraga Termometer dan setelah menggunakan alat peraga Termometer. Angket kreativitas belajar terdiri dari pertanyaan positif dan pertanyaan negatif. Skor-skor kreativitas belajar dapat dilihat pada tabel 2 .

Tabel 2. Skor-Skor Skala Sikap

\begin{tabular}{|l|l|c|l|c|}
\hline \multirow{2}{*}{ No } & \multicolumn{2}{|c|}{ Pertanyaan positif } & \multicolumn{2}{c|}{ Pertanyaan negatif } \\
\cline { 2 - 5 } & \multicolumn{1}{|c|}{ Skala sikap } & Skor & \multicolumn{1}{|c|}{ Skala sikap } & skor \\
\hline 1 & Sangat setuju & 5 & Sangat setuju & 5 \\
\hline 2 & Setuju & 4 & Setuju & 4 \\
\hline 3 & Kurang setujugh & 3 & Kurang setujugh & 3 \\
\hline 4 & Tudak setuju & 2 & Tudak setuju & 2 \\
\hline 5 & Sangat tidak setuju & 1 & Sangat tidak setuju & 1 \\
\hline
\end{tabular}

Angket kreativitas belajar digunakan untuk mengetahui pengaruh pengembangan alat peraga termometer sederhana terhadap kreativitas belajar siswa. Pada tabel 2 merupakan angket kreativitas belajar diberikan kepada siswa yang disusun berdasarkan kisikisi pada tabel 3 . 
Tabel 3. Angket Kreativitas

\begin{tabular}{|c|c|c|c|}
\hline No & $\begin{array}{c}\text { Aspek yang } \\
\text { diukur }\end{array}$ & Indikator-indikator kreativitas & $\begin{array}{c}\text { Nomor } \\
\text { item }\end{array}$ \\
\hline \multirow[t]{3}{*}{1} & \multirow[t]{3}{*}{ Fleksibilitas } & \begin{tabular}{|ll}
$\begin{array}{l}\text { Menghasilkan gagasan } \\
\text { pertanyaan yang bervariasi. }\end{array}$ & jawaban, atau \\
\end{tabular} & 1,2 \\
\hline & & $\begin{array}{l}\text { Dapat melihat masalah dari sudut pandang } \\
\text { yang berbeda-beda. }\end{array}$ & 3,4 \\
\hline & & $\begin{array}{l}\text { Mencari banyak alternative atau arah yang } \\
\text { berbeda-beda }\end{array}$ & $5,6,7$ \\
\hline \multirow[t]{3}{*}{2} & \multirow[t]{3}{*}{ Originalitas } & $\begin{array}{l}\text { Mampu melahirkan ungkapan yang baru dan } \\
\text { unik. }\end{array}$ & 8,9 \\
\hline & & $\begin{array}{l}\begin{array}{l}\text { Memikirkan cara yang tidak lazim untuk } \\
\text { memikirkan diri. }\end{array} \\
\end{array}$ & 10,11 \\
\hline & & $\begin{array}{|lll|}\begin{array}{l}\text { Mempunyai kemauan } \\
\text { menyelesaikan tugas. }\end{array} & \text { keras untuk } \\
\end{array}$ & 12,13 \\
\hline \multirow[t]{5}{*}{3} & \multirow[t]{5}{*}{ Elaborasi } & $\begin{array}{lll}\text { Menanggapi pertanyaan-pertanyaan } & \text { secara } \\
\text { bergairah,aktif dan bersemangat } & \text { dalam } \\
\text { menyelesaikan tugas-tugas. } & \end{array}$ & 14,15 \\
\hline & & $\begin{array}{l}\text { Berani menerima atau melaksanakan tugas } \\
\text { berat. }\end{array}$ & 16,17 \\
\hline & & $\begin{array}{l}\text { Senang mencari cara atau metode yang praktis } \\
\text { dalam belajar. }\end{array}$ & $18,19,20$ \\
\hline & & Kritis dalam memeriksa hasil pekerjaan & 21,22 \\
\hline & & \begin{tabular}{|l} 
Agresip bertanya. \\
\end{tabular} & 23,24 \\
\hline \multirow[t]{2}{*}{4} & \multirow[t]{2}{*}{ Kefasihan } & $\begin{array}{ll}\text { Mencetuskan } & \text { banyak } \\
\text { gagasan,jawaban,penyelesaian masalah atau } \\
\text { pertanyaan. }\end{array}$ & $25,26,27$ \\
\hline & & $\begin{array}{l}\text { Mandiri dalam belajar alat peraga termometer } \\
\text { sederhana. }\end{array}$ & $28,29,30$ \\
\hline
\end{tabular}

(Wulandari,2010)

\section{HASIL DAN PEMBAHASAN \\ Metode Penelitian Tahap I \\ Potensi dan Masalah}

Berdasarkan hasil observasi peneliti, di SMPN 19 Mataram ditemukan permasalahan terkait dengan pembelajaran fisika. Salah satunya adalah para siswa sedikit sekali yang tertarik pada pelajaran fisika. Hal ini disebabkan adanya anggapan bahwa pelajaran fisika banyak sekali rumus-rumus dan sukar dipahami. Sikap mereka terhadap fisika bisa dilihat dengan kurang adanya perhatian sampai penolakan mendalam. Dalam hal ini, guru selaku tenaga pengajar hendaknya bisa lebih kreatif dalam mengelola atau mendesain kegiatan pembelajaran agar pembelajaran menjadi lebih menyenangkan. Jika para siswa senang belajar fisika,

tentu mereka bisa menjadi lebih aktif. Keaktifan yang dimaksud disini tentu saja keaktifan yang mampu melibatkan mental dan emosionalnya.

Dalam menciptakan kondisi belajar siswa aktif tersebut, diperlukan suatu pengembangan alat peraga. Pengembangan alat peraga adalah mengembangkan media alat bantu pembelajaran dan segala macam benda yang digunakan untuk memperagakan materi pelajarandapat memberikan pembelajaran menjadi lebih menarik, lebih jelas dan lebih mudah dipahami. Dalam fisika, alat yang biasa digunakan adalah slide, film, gambar, poster, Lembar Kerja Siswa (LKS), kaset pita suara, daftar dinding dan lain-lain. Alat peraga termometer sederhana ini berisi kegiatankegiatan terprogram yang langsung dilengkapi dengan alat dan bahan sederhana yang ada di kehidupan kita sehari-hari sehingga mampu memberikan kesan mudah bagi siswa.

\section{Desain Awal Produk}

Kondisi pada potensi dan masalah yang ada mendorong peneliti untuk mengembangkan evaluasi berupa alat peraga termometer sederhana. Termometer sederhana memiliki kelebihan antara lain dapat meningkatkan kreativitas siswa dalam proses belajar. Selain itu juga alat peraga termometer sederhana ini terdiri dari alat dan bahan. Sehingga termometer sederhana ini telah di praktekkan oleh siswa-siswa SMPN 19 Mataram.

Pengembangan alat peraga termometer sederhana yang telah dihasilkan yaitu terdiri dari alat dan bahan, rumus fisika, dan soal hitungan. Alat peraga termometer sederhana yang dibuat memiliki tampilan yang menarik dan mudah untuk dipraktekkan.

\section{Hasil Validasi Ahli}

Pengembangan alat peraga yang telah didesain divalidasi oleh ahli sebelum diuji coba. Validasi termometer sederhana dilakukan oleh 4 ahli.

Hasil validasi dari ahli praktisi mengatakan tidak ada revisi terhadap produk karena sudah dikatakan layak untuk digunakan.Hasil yang berbeda diperoleh dari ahli I,II dan III merekomendasikan perbaikkan mengenai tampilan alat dan skalanya harus ada.Hasil validasi ahli menunjukkan bahwa pengembangan alat peraga termometer sederhana layak digunakan dalam pembelajaran setelah melakukan revisi.

\section{Revisi Produk}

Produk alat peragatermometer sederhana yang telah divalidasi pada bagian gambardesain harus lebih menarik, dan warna alkoholnya harus cerah.

Hasil validasi ahli I, II, dan III mengatakan ada revisi terhadap produk. Hasil yang berbeda diperoleh dari praktisi.Praktisi merekomendasikan revisi pada bagian alat dan bentuk menarik. Hasil validasi ahli menunjukan bahwa pengembangan alat peraga termometer layak digunakan dalam mempelajaran setelah melakukan revisi. Untuk lebih jelas perhatikan tabel ini:

Tabel 6. Hasil Validasi Kriteria Keterkaitan dengan Bahan Ajar

Tabel 6 Hasil Validasi kriteria Keterkaitan dengan bahan aja

\begin{tabular}{|c|l|c|c|c|c|c|c|}
\hline \multirow{2}{*}{ No } & \multirow{2}{*}{ Nama Validator } & \multicolumn{2}{|c|}{ Skor Item } & & \multirow{2}{*}{ Joal } & \multirow{2}{*}{ Kriteria } & \multirow{2}{*}{ Nilai } \\
\cline { 3 - 8 } & & 1 & 2 & 3 & & & \\
\hline 1 & Zulkarnain. M.Si & 5 & 5 & 5 & 15 & Sangat Baik & A \\
\hline 2 & Islahudin.M.Pfis & 2 & 4 & 4 & 10 & Baik & B \\
\hline 3 & Ni wayan Sri Darmayanti,M.Pd & 4 & 4 & 4 & 12 & Sangat Baik & A \\
\hline 4 & Fahrunnisa, S.Pd & 5 & 4 & 4 & 13 & Sangat Baik & A \\
\hline
\end{tabular}


Tabel 6. Hasil Validasi Kriteria Nilai Pendidikan

\begin{tabular}{|c|c|c|c|c|c|c|}
\hline \multirow{3}{*}{ No } & \multirow{3}{*}{ Nama Validator } & \multirow{2}{*}{\multicolumn{2}{|c|}{$\begin{array}{c}\text { Skor Item } \\
\text { Soal }\end{array}$}} & \multirow{3}{*}{ Jumlah } & \multirow{3}{*}{ Kriteria } & \multirow{3}{*}{ Nilai } \\
\hline & & & & & & \\
\hline & & 1 & 2 & & & \\
\hline 1 & Zulkarnain. M.Si & 5 & 5 & 10 & Sangat Baik & $\mathrm{A}$ \\
\hline 2 & Islahudin.M.Pfis & 3 & 4 & 7 & Baik & $\mathrm{B}$ \\
\hline 3 & Ni wayan Sri Darmayanti,MPd & 5 & 5 & 10 & Sangat Baik & $\mathrm{A}$ \\
\hline 4 & Fahrunnisa, S.Pd & 4 & 4 & 8 & Sangat Baik & $\mathrm{A}$ \\
\hline
\end{tabular}

\section{Metode Penelitian Tahap II}

Penggunaan pengembangan alat peraga termometer sederhana di SMPN 19 Mataram untuk meningkatkan kreativitas belajar siswa pada mata pelajaran FISIKA materi Suhu dan Kalor.Sebelum menerapkan pengembangan alat peraga termometer sederhana, siswa mengisi angket kreativitas belajar yang sebelumnya telah divalidasi.Angket yang telah diisi oleh siswa kemudian diolah untuk mengetahui besar kreativitas siswa.

Kreativitasbelajar siswa diolah berdasarkan indikator masing-masing.Jumlah semua indikator adalah 4.Untuk indikator Fleksibilitas jumlahnya ada 8 dimana sebelum menggunakan alat peraga termometer sederhana $117 \%$ dan setelah penerapan meningkat menjadi $330 \%$. Kriteria peningkatan kreativitas dikorelasikan dengan kriteria gain dimana diperoleh hasil peningkatan kreativitas belajar siswa sebesar 0,69 dan berada pada kategori sedang. Aspek kreativitas belajar yang kedua adalah Originals dengan jumlah masingmasing 8 item sebelum dan sesudah dimana sebelum penerapan alat peraga termometer sederhana $185 \%$ dan setelah penerapan meningkat menjadi $344 \%$, dengan nilai gain sebenar 0,74. Dan Aspek kreativitas belajar yang ketiga adalah Elaborasi dengan jumlah masing-masing 8 item sebelum dan sesudah dimana sebelum penerapan alat peraga termometer sederhana $186 \%$ dan setelah penerapan meningkat menjadi $347 \%$, dengan nilai gain sebenar 0,76. Dan yang ke empat adalah Kefasihan dengan banyak item 6 , sebelum menggunakan termometer sederhana sebesar $143 \%$ dan setelah menggunakan menjadi $265 \%$ dengan nilai gain 0,78 .

Dalam pengukuran kreativitas belajar siswa digunakan teknik analisis data berupa data kuantitatif, yang diperoleh peningkatan dengan menggunakan normalisasi gain (gain) untuk kreativitas belajar berupa Fleksibilitas 0,69 dengan kriteria sedang, kreativitas belajar Originals 0,74 dengan kriteria Tinggi, kreativitas belajar Elaborasi 0,76 dengan kriteria Tinggi, dan kreativitas belajar Kefasihan 0,78 dengan kriteria Tinggi.

Berdasarkan penelitian yang telah dilakukan, pengembangan alat peraga berbasis home materials materi suhu dan kalor ini telah teruji keefektifannya dan mempunyai pengaruh terhadap peningkatan kreativitas belajar siswa di SMPN 19 Mataram.

\section{SIMPULAN DAN SARAN Simpulan}

Berdasarkan penelitian yang telah dilaksanakan dapat disimpulkan bahwa pengembangan alat peraga berbentuk Termometer Sederhana dapat: 1) Teruji kevalidannya baik dari segi ahli media maupun materi, dimana untuk kriteria keterkaitan dengan bahan ajar semua ahli memberikan nilai $A$, untuk kriteria efesiensi alat 2 ahli memberikan nilai $A$ dan nilai $B$ dari 2 ahli yang lain, serta untuk kriteria nilai pendidikan 3 ahli memberikan nilai $A$ dan 1 ahli memberikan nilai $B, 2)$ Proses pembelajaran berjalan dengan lancar, karena respon siswa yang baik terhadap alat peraga Termometer sederhana Fisika yang menjadi sumber belajar bagi siswa, 3) Teruji keefektifannya karena mampu meningkatkan kreativitas belajar siswa kelas VII F SMPN 19 Mataram pada materi suhu dan kalor. Dimana diperoleh gain untuk kreativitas belajar berupa fleksibilitas 0,69 dengan kriteria sedang, kreativitas belajar berupa originals 0,74 dengan kriteria tinggi, kreativitas belajar berupa elaborasi 0,76 dengan kriteria tinggi dan yang terakhir kreativitas belajar berupa kefasihan 0,78 dengan kriteria tinggi. Sedangkan Peningkatan kreativitas belajar secara klasikal juga berada pada kriteria tinggi dengan normalisasi gain sebesar 0,74.

\section{Saran}

Saran-saran yang dapat dikemukakan sesuai hasil penelitian adalah : 1) Hasil penelitian ini dapat digunakan oleh guruguru SMP sederajat sebagai salah satu media belajar dan sekaligus sumber belajar yang bersifat suplemen atau tambahan, 2 ) Alat peraga termometer sederhana (fisika) ini dapat dikembangkan lagi dengan variasi desain dan gambar yang berbeda. Dapat juga dikembangkan pada materi lain untuk setiap pelajaran, kelas dan semester yang berbeda khususnya di sekolah menengah pertama (SMP).

\section{DAFTAR RUJUKAN}

Alfad, Haritsah. (2010). Pengembangan Lembar Kerja Siswa. (Online), (http://haritsah.ifastnet.com/home/38/5 0-lks.html, diakses 19 Februari 2017).

Ali,Muhammadi, (2013). Pendidikan Kependidikan Prosedur \& Strategi.Bandung : CV. Angkasa. 
Arikunto, Suharsimi. (2006). Prosedur Penelitian, Suatu Pendekatan Praktik. Jakarta: Rineka Cipta

$$
\text { (2015). Dasar-Dasar evaluasi }
$$

Pendidikan. Jakarta: Bumi Aksara.

Azhar, Arsyad. (2016). Media Pembelajaran. Jakarta: Rajawali pers.

Borg, W.R. \& Gall, M.D. (1989). Educational Research: An Introduction, Fifth Edition. New York: Longman.

Daryanto. (2011).

Pembelajaran.Bandung :Satu Nusa.

Dewi, Siska. (2011).Pengembangan Alat Peraga Pembelajaran Berbasis Teknologi murah Materi radiasi Kalor Dan Tekanan Hidrostatik : Lampung.

Diatri, Irina Fatin. (2014). Pengembangan Alat peraga IPA Berbasis Teknologi Murah Materi Tekanan Di SMP.Bandar lampung

Jamzuri. (2007). Desain dan Pembuatan Alat Peraga IPA. Jakarta: Universitas Terbuka

Musfiqon, HM. (2012). Pengembangan Media dan Sumber Pembelajaran.Jakarta: PT Prestasi Pustaka Publisher

Purwanto. (2002). Assessment Pembelajaran. Jakarta: Direktorat Jendral Pendidikan Tinggi Departemen Pendidikan Nasional

Richey, Rita C. \& Klein. (2007). Design and Development Research. London: Lawrence Erlbaum Associates. Inc.

Riyana, Cepi. (2008). KonsepdanAplikasi Media Pembelajaran. Jakarta: Mercubuana

Sadiman, A.S., Raharjo, Dan Lain-Lain. (2010). Media Pendidikan Pengertian, Pengembangan, dan Pemanfaatanya. Jakarta: Pustekom dan PT Raja Grafindo Persada

Sanjaya, Wina. (2009). Perencanaan dan Desain Sistem Pembelajaran. Jakarta: Prenada Media Group.

Santyasa, I Wayan. (2007). Landasan Konseptual Media Pembelajaran. Yogyakarta: Undiksha

Setyosari, Punaji. (2010). Metode Penelitian Pendidikan dan Pengembangan.Jakarta: Prenada Media Group

Sugiyono, (2010). Metode Penelitian Dan Pengembangan (research and Development/R\&D. Bandung : Alfabeta

Supritpria, (2014). Percobaan Fisika Asyik: Termometer sederhana : Yogyakarta

Suyanto, Eko. (2009). Pengembangan Contoh Lembar Kerja Fisika Siswa dengan Latar Penuntasan Bekal Awal Ajar Tugas Studi Pustaka dan Keterampilan
Volume 6, Nomor 1, Mei 2020. p-ISSN : 2460-9587 e-ISSN : 2614-7017

Proses Untuk SMA Negeri 3 Bandar lampung.Prosiding Seminar Nasional Pendidikan 2009. Bandar lampung: Unila, diakses 17 Februari 2017

Triyanto. (2010). Model Pembelajaran Inovatif Berorientasi Konstruktivistik. Surabaya: Prestasi Pustaka

Uno, Hamzah B. (2007). Perencanaan Pembelajaran. Jakarta: Bumi Aksara 